\title{
Singing up Country in the Poetry of Judith Wright and Pablo Neruda
}

\author{
Stuart Cooke
}

$\mathrm{P}$ ABLo Neruda (born 1904) and Judith Wright (born 1915) are world poets. Not only has their work been widely read within the worlds of Spanish and English literatures, but their poems are very actively attuned to the variety of processes that compose the world itself. After growing up in quite remote parts of their respective countries, each poet always sought to speak beyond his or her immediate locale. To read their work is to observe an intersection of Romantic and modern sensibilities, where a love for the natural environment is tempered by political imperative: to liberate Chile from capitalist rule, in the case of Neruda, or to liberate Australia from colonialist modes of destruction, in the case of Wright. What we also see is the extent to which each poet's perception of the natural world was reflective of their relationships to their nations' histories.

Many Australian readers are familiar with Wright's work but Neruda remains, unfortunately, somewhat less understood. While he is undoubtedly the most widely-read poet of the twentieth century, much of the texture of his work remains hidden from Australian audiences by both the Spanish language, and the failure of Australian scholars to pay serious attention to the contexts of Latin American - and, particularly, Chilean - poetry. Unfortunately, what we miss by keeping Neruda at a distance is the opportunity to explore the poetics of a writer who was in many ways something of a kindred spirit of Wright's. A reading of Neruda and Wright in company presents an opportunity to add a richer, global context to the life and times in which the great Australian poet was working.

Neruda, born in southern Chile and christened Neftali Ricardo Reyes Basoalto, had emerged as a household name in much of South America by his early twenties. In 1923 his first volume of verse, Crepusculario ('Book of Twilights'), was published, followed the next year by Veinte poemas de amor y una canción desesperada ('Twenty Poems of Love and a Song of Despair'). In much the same way as Wright's second volume, Woman to Man (1949), became her most popular, Veinte poemas became Neruda's best-known work, eventually selling millions of copies around the 
world. Like Woman to Man, these early, surrealist love poems describe landscapes in terms of the female body, but whereas Wright's celebrate their femininity, Neruda's speakers possess an unequivocal masculinity (Brotherson 101). The early Neruda saw sensuality as a path to a form of transcendence; it was not until he ventured to Spain that he began to recognise the power and significance of the land itself.

Appearing a year after Wright's first volume, The Moving Image (1946), Tercera Residencia ('Third Residence', 1947) is Neruda's first sustained exploration of the function of landscape as an entity not always the result of the subject's own, interior state. Although he had left Spain some years before its publication, his experiences on the peninsula had left Neruda with permanent scars. Civil war had ravaged the country and one of his closest friends, poet Federico Garcia Lorca, had been executed by Francisco Franco's forces. Wright's evocation of death in The Moving Image (1946) in poems like 'Bora Ring' and 'Nigger's Leap: New England' tightly binds the poems to their locales; significantly, it is death that likewise catalyses Neruda's own profound attachment to the land. In this respect, 'Como era España' is perhaps the most important poem in Tercera Residencia.

\section{What Spain Was}

Strained and dry, Spain was a diurnal

drum of dull sound, smooth, open country, the eagles' nests, silence in the whipped-up elements.

How, until the lamentation, until the soul, 1 love your harsh soil, your rough bread, your poor people; how, until the deepest part of my being, grows the lost flower of your villages, wrinkled, immovable, and your mineral country, spread under the moonlight, through the aeons and devoured by a fool of a god.

All your structures, your animal solitude fused to your intelligence, surrounded by the abstract stones of silence, your sharp wine, your gentle wine, your violent and delicate vineyards.

Sun stone, pure among the regions of the world, Spain laced with bloods and metals, blue and victorious, people of petals and bullets, alive alone, and sleepy, resonant. (Cooke 76) 
In this translation 1 have tried to make the poem as Australian as possible, so that one of its most startling features is this very 'Australian-ness', the evocation of colours and elements, of terrain 'Strained and dry ... smooth, open', which are so familiar to Australian readers. Also present is the very strong, and very Antipodean, sense of the relative smallness of things in such an enormous landscape, and of the predominating silence. What is even more interesting is the position of this landscape. It is a presence that is potent in materialist and non-materialist senses; it is what might be termed a 'World'.

For Martin Heidegger, the world is not only a physical object, not a simple picture of the planet Earth or of the parts of it which may be familiar. As he outlines in the famous essay, 'Building Dwelling Thinking' (149-51), 'World' incorporates a matrix known as the four-fold, which is a breathing intersection of earth, sky, human and divine. To be aware of the four-fold is to dwell there. 'Dwelling' involves poetically attuning one's thoughts and actions to that which is given by the natural environment. It also involves an awareness of the presence of spirits or spirit-beings in places, of the incalculable possibilities of the divine. To dwell in the four-fold is to create and carefully to preserve things and places. Places are to be cared for because they, together with the things in them, disclose the very interweaving, or the 'gathering' of all four folds - they create, in other words, our World. This is significant in the context of 'What Spain Was' because the poem recollects that very same experience of the four-fold - of the gathering, that is, which Neruda felt take place in the dry, dramatic Spanish country. 'Country', too, is an important term, for 'What Spain Was' is one of the first instances in Chilean poetry of a modern, European subject singing to the earth in a manner already quite common in much Australian poetry of the same period.

Martin Harrison argues that a defining quality of Australian poetry 'is a prevalent sense that "country" is something you are a part of, something which changes your senses of self and placement and which requires a change in envisioning if you are to see it and understand it' (54). In 'What Spain Was', the land goes 'until the soul' of the speaker's being. It is, to quote Harrison again, 'active and malleable ... and ancestral' (54). Writing amidst the turmoil of war, it was almost inevitable that Neruda would see the blood of those he loved in Spanish soil. However, he also saw the ways in which this subterranean, historical presence gave the land an intelligence, a being, however 'sleepy', beyond the calculations of its people. This is country. The poem suggests to us the ways in which Neruda was starting to look towards the land for a kind of negative transcendence. It was by singing into place, in other words, that he thought he would save first his own soul, and then the souls of his compatriots, from the oppressions of their colonial history. After all, 'those who destroy their country destroy themselves' (Rose 154), and Neruda, like Wright, was a decidedly vitalistic poet. 
With this reference to 'singing' I am placing the emphasis on the notion of a song as a performance. In Australian contexts, the act of 'singing up' something is laden with meanings that are almost exclusively Aboriginal ones. In performance, some Aboriginal songs have the power to regenerate country, to revive connections between people, plants and animals, and with the ancestors who brought them all into being. I want to argue here that 'singing' for Wright and tor Neruda - that is, the conception of their poetry as a performance - shared some of these intentions. Neruda is very deliberate about his poetic attempts to reinvigorate reality. He seeks to place 'eyes and tongues into every ... inanimate object', turning the world 'to glass' (Franco 13). Indeed, in Wright's most optimistic poems poetic language has the potential to breach the division between man and nature, a division hitherto enforced by an overuse of the non-poetic: language that is rational, universal and empirical (Walker 101). In 'For Precision' she writes that the poet's vision 'joins all, gives all meaning, makes all whole' (Selected 97). For both poets, poetic language is a way of affirming and performing the subject's connection to the living world.

Of course, the concept of a song involves not only its musicality but also the ways in which it is performed. Songs do not come into being until they are embodied by a singer and sung. Much of Neruda's poetry was conceived specifically for an audience, to be delivered as a form of oratory, bold and impassioned, performative. Wright, too, was known for her brilliant reading skills, her ability to turn her readings into pieces of dramatic theatre. Franco writes of Neruda, and we could also say of Wright, that the poems 'were never intended to be merely script or signs on a printed page but were to be uttered and declaimed in order to elicit a response' (17).

This element of activity and activism in their work cannot be overstated, and again it has Heideggerian connotations.' Implicit in Heidegger's concept of the four-fold is the equally complex concept of poiesis, or the 'bringing forth' of place. For Heidegger, poiesis is not confined to artistic practice; it extends, says Kate Rigby, 'to a whole way of life' (430). In this manner, then, it is also a kind of praxis: 'that of knowing how to dwell'. This tinges Heideggerian poiesis with a thoroughly

\footnotetext{
1 Perhaps surprisingly, Heidegger's work had great resonance with Wright's critical thinking, too. In an essay about the poet Jolun Shaw Neilson. whom she deeply admired. Wright said that the poet's place is always 10 alfirm Neilson's 'folly of Spring' - 10 remain, that is, the adversary of 'Stony Tow'l, which 'Tollows no curve but the straight line and the square' (from 'The Bard and the Lizard'). Neilson detested empirical measures that denied the flourishing of life by enframing or confining it; for Wright, his appeal to spring's folly was a reminder that 'a truth does reside in the imagination that cannot be comprehended in abstract formulae'. Like Neilson and then Heidegger, she saw real danger to humanily in laking refuge from ourselves in 'a purblind notion of empiricism'. Only poctry, she wrote, could take proper account of the lact that we live by the folly of spring. Iust as Heidegger salid that the task of the poct was to draw from the darkness 'the Being of beings", or to reveal to man the complex web of divine and mortal forces that he termed both 'Nature' and 'the venture' ("What Are Poets For?' 134), Wright was also adamant that the poet should remind us of our ecological situation. That, she wrote, "is finally what the poet is lor' (Becense 44-45).
} 
activist, if not political, colour (Rigby 430). Originally, writes Heidegger, the Greek arts were not enjoyed aesthetically but had an extremely practical application in their 'poetic revealing' ('The Question Concerning Technology' 316). In the same way, what is vital to keep in mind when reading Neruda's and Wright's poems is the extent to which they function as practical as well as aesthetic objects, and how they represent, by extension, expressions of the poets' inner-most convictions concerning their relationships to the world.

By the time he reached his forties Neruda was reading his poetry at trade union meetings and political rallies, the first instance of which he described as 'the most important fact in my literary career' (qtd in Franco 17). Of course, as Wright became increasingly involved with activism her poetic output declined, but it is not hard to see how the seeds of this activism, of this speaking out, germinated in her poetic thought. Throughout her life she had a strong desire to reveal what she saw as the places in greatest need of care, which is to say that she was always singing, in one form or another. Neruda, on the other hand, who enjoyed such tremendously large audiences, never needed to question the efficacy of his poetry in terms of his politics. Once again, this returns us to the relationship between the verb - to sing - and its correlated noun. For these poets, writing poetry was not a process that began and ended within the poet. As much as they were moved to write by what was taking place in the world around them, Wright and Neruda wrote because they believed they had the capacity to implement forms of material change upon the world.

For Heidegger, it was Friedrich Hölderlin who was cast out into that Between, between the gods and his fellow mortals, and who named the 'holy', giving worldly weight to what he was shown by the gods (Brock 170-71). The poet's power came from a non-earthly, transcendent entity. Following on from this, 'it is precisely in the naming of the gods, and in the transmutation of the world into word, that the real conversation, which we ourselves are, consists' ('Hölderlin and the Essence of Poetry' 279). Yet Neruda is not looking skyward for the source of the holy. Instead, as we see in 'What Spain Was', the land is 'God': it is the object of praise and a source of spiritual renewal, providing, therefore, the capacity for negative transcendence. Still quite Heideggerian, however, is Neruda's belief that by transmuting the world around him into the word he would begin 'the real [Chilean] conversation' that would bring his country into a new being.

This 'real conversation' has distinctly primordial origins. Since the dawn of time, Heidegger tells us, 'the basis of our existence has been a conversation' ('Hölderlin and the Essence of Poetry' 280). It was Neruda's aim to reclaim the basis of his own community's existence from a history of colonial and capitalist oppression. His new conversation, therefore, would need to begin beneath this history. For Neruda this conversation came from the soil; his poem would need to sing of what came from 
the ground, rather than from the powers in the sky above. Here lies the original purpose of his greatest work, Canto general ('General Song', 1950): to reinhabit the land and reconnect it to the organic matter of Chilean flesh. In the poem's grand sweep Neruda affirms his new role: to become, in Alastair Reid's words, 'a voice, a voice for the dead past, for the stones themselves, for the inanimate world of objects, for the natural world, for the continent in all its myriad forms, and, above all, for those in the present who lack a voice' (5). Its entire, monolithic narrative is predicated on a singing-into-being of the earth - of the geology, the flora and the fauna from which the Canto - the song - can then grow:

Man was dust, earthen vase, an eyelid

of tremulous loam, the shape of clay...

Tender and bloody was he, but on the grip

of his weapon of moist flint,

the initials of the earth were

written.

'A Lamp on Earth', Canto I (Neruda 13)

A truly Heideggerian poet - someone in the mould of Rainer Maria Rilke or Hölderlin - might have composed their poems in solitary communion with the divine. Neruda, however, wrote Canto general amidst a flurry of political passion. He had broken away from previous notions of poetry as a detached, elite form, and 'established a whole web of connection not only with poets ... but with the people of Chile, people who both knew of him and knew his poems, very often by heart' (Reid 6). As the vast work was unfolding, Neruda was elected to the Chilean senate; when Canto general was published it received far wider immediate attention than any of his previous work, as much for its boldness as for its poetry (Reid 5). According to Edwin Williamson, Canto general was to have 'an enormous emotional and psychological influence on Latin American nationalists, shaping attitudes to progress and to the outside world' for years after its publication (492). While the passion of Neruda's politics and the savagery of his diatribes against injustice made some of the sequences overly polemical (as was the case with some of Wright's most politically-charged poems), this intensity of feeling was to contribute immeasurably to invoking something of a new Chilean consciousness. It began, in the most literal interpretation of the word, a 'conversation' about the country (the 'world') it had transmuted into word.

Canto general can be read silently, but its mode is primarily vocative. 'In a sense,' writes Reid, '[Neruda's] voice was the instrument for which he wrote'. Mesmerising in its measure, 'unforgettable to any who ever heard him read', his voice had an extraordinary range of manners (6). The book is not an internal monologue; it is, rather, a kind of eco-socialist manifesto, a general chant, sung by the poet and the people alike to celebrate the Latin American cornucopia. Rather than standing 
alone as a 'pure' object of artistic transcendence, the work transcends negatively: in performance, with the poet's voice, it travels laterally, across and through the people and the landscape, and is left there to resonate. This aspect of Canto general - its functions as a piece of writing, as a narrative, and as a script - allows it to achieve something of the complexity we might find in the performances of Australian Aboriginal song, in which, according to Allan Marett, the focus is on the performance itself, in constructing it in a conventionally and aesthetically pleasing way. 'To develop an appreciation of how singers and dancers put their performances together' Marret suggests, 'is to approach the core of the poetics and aesthetics of their tradition' (81). This tells us something about the power of the Canto general as well: while we may, as scholars, criticise its moments of polemic, the book's primary purpose was to be and to elicit a performance, to sing the country into existence:

Glean from the lands the shrouded

throb of sorrow, the solitude, the wheat of the threshed fields:

something germinates beneath the flags:

the ancient voice calls us again.

Descend to the mineral roots ... (Neruda 148)

For Wright, too, poetry had to 'Descend to the mineral roots' for she also saw within in it a re-creative function. Poetry, she wrote, 'has to show a way down, into, back and beyond or it's no poetry'. Coupled with this faith in her craft, however, was a corresponding lack of faith in the ability of her poems to reach those minds she thought were in most need of reaching, writing that 'at a time when none of us want to look at the reality of ourselves, such poetry is not welcome to anyone' (qtd in Clarke and McKinney 443). Indeed, Wright's lack of a large audience was a central reason for the decline of her creative output in later years. As she wrote in a letter from 1989, 'I'm not writing poetry now, since what I have to do is push my barrows, hoping that one at least will get unloaded in the right place, and very few people read poetry and even less know what it's about' (qtd in Clarke and McKinnney 443). Clearly, Wright's intention was very similar to Neruda's, in that she too sought to start a new conversation about the relationships that people had to the world around them. Yet we must also keep in mind that the comparatively weaker public presence of Australian poetry made her far more sceptical of the power of poetry than Neruda ever was.

In his reading of Hölderlin, Heidegger suggests that the gods, by initiating with man the great conversation, brought about language and speech. Through and in the word was established what is both lasting and significant for the human being. Up to that moment, however, humans, like other species, existed in a flux 'where no consciousness could fix on anything' (Brock 185). Then they acquired the 
experience of the gods: a single, unending present, 'the experience of something remaining and constant that brings about language and speech' (Brock 186). Importantly, in Heidegger's account it is "the gods" very much more than the things of common life' that initiate language (Brock 186). Here, language is born of a transcendent constant detached from the cycles of the earth. For Wright, this same flux of experience existed prior to all speech; it was only because of an object or an event's constant recurrence and/or utility that it acquired the status of a concept and was then named (Wright, Because 170). Her negative transcendentalism, however, was in her pinpointing of the word's emergence in communal and social - not divine - contexts. Communication, she wrote, was only necessary where there was a co-operative view of the world; if an individual was solitary such a need did not exist (Because 170). Language, that is, came from those 'things of common life' (Brock 186). A relationship between multiple humans and the multiplicity of the surrounding world engendered a system of objectification. There was no pure, transcendent Word; like Canto general, Wright's language connected laterally and was always in touch with the ground.

Poems like 'Interplay' and 'Flame Tree in a Quarry' are explorations of this lateral intertwining of the imagination, language and the world. In 'Interplay', what is within the mind 'becomes what is around'. As the speaker is a 'mirror' to the world's 'blaze and sound', so too does 'the ordering image' sear the world with a stirring, bright light (Wright, Selected 141). So, in 'Flame Tree' it is from 'the torn earth's mouth' that poetry emerges. The song is stilled when it is 'made flesh' so that the singer's body is the 'flesh of the world's delight' and her words are the 'voice of the world's delight'. 'Out of the very wound' - from those mineral roots - bursts the 'scarlet breath' that fills the poet with fire (Selected 48). The scarlet breath is a manifestation of the word, which itself emerges from the primal, creative life-force (Walker 58). This is an account of Wright's most positive, energised description of an inextricable unity between the perceivable world, the flesh of the body and poetic language.

'The Cicadas', from her 1953 volume The Gateway, is another important poem in this context, not only for the way in which it, like the much larger Canto general, descends into the earth in order to find an origin, but also for the primary importance it assigns the power of the voice and of song. 'For a whole life' the cicadas 'have crouched alone and dumb' in 'the humble dark' of 'the world below the world'. Time, including past and future, had no meaning; they existed in a pre-linguistic state in which 'they neither slept nor woke,' but 'dreamed vaguely the dreams of the tree' in which they had burrowed. Now, however,

$\ldots$ in terror overhead their day of dying breaks.

The trumpet of the rising sun bursts into sound 
and the implacable unborn stir and reply.

In the hard shell an unmade body wakes

and fights to break from its northerly-enclosing ground.

These dead must dig their upward grave in fear

to cast the living into the naked air.

Terrible is the pressure of light into the heart.

The womb is withered and cracked, the birth is begun, and sluddering and groaning to break that iron grasp the new is delivered as the old is torn apart.

Love whose unmerciful blade has pierced us through, we struggle naked from our death in search of you.

This is the wild light that our dreams foretold while unaware we prepared these eyes and wings while in our sleep we learned the song the world sings. Sing now, my brothers; climb to that intolerable gold.

(Wright, Selected 77-78)

This is a strikingly Romantic metaphor of human history: crouching 'alone and dumb' in the primordial depths of the earth, the cicadas will be wrenched out of their slumber by the song 'of the rising sun' and brought into an embrace with the golden world. Furthermore, the particular attention to genesis-in-ground relates very strongly to Neruda's work. The conception of the past as having emerged from, and then decomposed and dissolved back into, the earth, and of the ways this earth can be entirely regenerative, is central to the Canto general. The Canto begins in a mythical, primordial time of molten geology and biology precisely so that, with the power of the spoken word, Neruda can sing Chile and its people into a proud, new being. The song soars outwards and resonates with the landscape, and then regenerates it. In both cases, then, 'the wild light' that the poets' 'dreams foretold' - this imminent, arriving world - is to be greeted with song. 'Sing now,' Wright calls to her insect-brothers, 'climb to that intolerable gold'.

What is being exploited here is an extremely intimate relationship between the poetic voice and the dynamic, animate reality into which it is sung. Prosaic writing can organise time into linear streams of negativity, where what is written down has always already taken place, and can never occur again after that which succeeds it. A poem like 'The Cicadas', however, or an opus like Canto general, is born of a belief that the awesome flux of experience - of time, sense, memory and anticipation - can be contained within the multi-temporal, multi-sensual framework of the poem and then sung out again, and again. It is the word which carves out a sense of that which remains and is constant. The performance of an entire poem, then, can reopen time, take hold of it, and splice it. This is to say that it was their understanding of the air in which the voice becomes, rather than the page on which the poem sits, which gives the work of these two poets so much power. For David 
Abram, our disregard for the air around us is a most profound expression of our environmental oblivion, for it is the air that most directly envelops us. It is, he says, 'that element that we are most intimately in' (260). As long as we see the air as mere empty space we can deny our interconnectivity with other things (Abram 260). In the performance of a poem like 'The Cicadas', therefore, we recall not only the foregrounding of animate being in the dark matter of the Earth but we are re-affirming our connection to, and responsibility for, the world. To 'sing up' something implies both that the world can listen, and also that, having heard the song, the world might be able to keep singing of its own accord.

While in 'The Cicadas' Wright called for the nascent creatures to 'climb to that intolerable gold', Neruda first climbs to this gold - found at the heights of Macchu Picchu, an Incan city in the high Andes - and then entices his compatriots to follow.' Perhaps the single, boldest distinction between these two poets can be made with reference to the ways in which they positioned themselves with relation to the rest of their community. Wright's understanding of the relationship between Australia's past and its present was startlingly different to how Neruda looked upon his own nation's development. Wright, as is well-known, was a passionate supporter of Aboriginal peoples' rights, and wrote various articles and books about the subject. More importantly, she maintained individual relationships with Indigenous people and was keenly aware of their struggles for recognition and justice, and of the evolution of their contemporary culture. Neruda, exalted as a poet and desperate for revolution, saw little problem assuming a podium high above his country's inhabitants and proclaiming to speak for all of them. As such, he was much more problematic in representing Indigenous Americans. When he is atop Macchu Picchu in the Canto, he mourns, quite beautifully, for those who once inhabited the ancient city:

Today the empty air no longer weeps, no longer knows your feet of clay, has now forgotten your pitchers that filtered the sky when the lightning's knives emptied it, and the powerful tree was eaten away by the mist and felled by the wind. It sustained a hand that fell suddenly from the heights to the end of time. You are no more, spider hands, fragile filaments, spun web:

all that you were has fallen: customs, frayed syllables, masks of dazzling light.

'The Heights of Macchu Picchu', Canto VII (Neruda 35)

2 Indeed, it is commonly thought that the vision for the entire Camto general came during this pilgrimage (Reid 5). 
Neruda was as passionate in his lamentations for Indigenous peoples' deaths as was Wright in her work. Nevertheless, having seen Macchu Picchu, Neruda proclaims, 'Yo vengo a hablar por vuestra boca muerta' ('I am going to speak for your dead mouth'), thereby ignoring the fact that over one million of this particular city's descendants were very much alive in the surrounding Andean region (Brotherson 51). These descendants, living evidence of the city's evolution, were probably far better-placed to restore Macchu Picchu to something of its former grandeur. Neruda's vision of an apparently 'dead' Macchu Picchu, then, is an arguably deliberate evasion of a live, Indian America.

As Wright approaches a keener sense of her own landscape, she avoids such colonialist overseeing by willingly singing of what she is unable to see. Nowhere is this more evident than in The Moving Image, in which a sense of absence, and the death from which it has resulted, pervades. In 'Nigger's Leap: New England', for example, 'the climbing dark' is as inevitable as the tides: colonial expansion has erased the presence of the 'thin black children' and has flooded the landscape 'suddenly as history' (Selected 11). The Moving Image laments these absences as if the poems themselves were somehow complicit in the destruction, which is to say that the poems lament because they can identify, but not recover, these silences. The poem 'Bora Ring' (Selected 3 ) is not a vehicle with which Wright recovers something of the vitality the ring once had in ceremony, in what would be an attempt to regenerate an otherwise non-descript, grassy mound. Rather, the 'song is gone' and the dancer's ritual is 'useless', the painted bodies of the dancers are nothing more than 'a dream the world breathed sleeping and forgot'. For Wright, her keen awareness of Indigenous history precluded her from including Aboriginal Australia in her songs.

It is here that some knowledge of the distinct colonial histories of Australia and Chile is useful. Neruda was at work in a country where the divisions between Indigenous and non-Indigenous people had different characteristics to those in Australia. In contrast to colonists of Australia, Spanish settlers interacted consistently and closely with many different groups of Indigenous Americans, whose services they actively sought to include (or exploit): colonial towns relied heavily on Indigenous communities for trade and labour supplies, for example. Furthermore, largescale conversions of Indians to Catholicism, followed by continent-wide fights for independence from colonial rule, meant that at the beginning of the twentieth century - while Australia's newly-formed federation had excluded Aboriginal people - Indigenous Latin Americans were fighting for relatively common religious, political and social goals. Though they operated with different priorities, emerging movements like Neruda's communists were no less inclusive. So, while we cannot ignore the fact that contemporary Indian Americans had litle presence in Neruda's work, it is also important to realise that to write about Chile's pre- 
colonial past was not to steal foreign artefacts from another culture and carry them back, T.G.H. Strehlow-like, to an imperial centre of civilisation, nor to remove the text from its context. Rather, Canto general needs to be read as an attempl to use what was available amidst the Chilean community to prise off and repel what the poet thought was the source of the entire country's pain.

After the success of Canto general, Neruda became preoccupied with poetry of still greater clarity, which would communicate even more effectively with the wider public. The publication of Odas elementales ('Elemental Odes') in 1954 marked a turn away from the ceremonial, if less symbolic, rhetoric of his previous work towards a poetry 'intended to be as natural as song'. After many years spent travelling across the globe he became more sedentary, and entered what seemed to be an 'almost religious communion with the natural world' (Franco 19-21). The stones of Chile became more mysterious, more unearthly; he seemed to move even closer to Wright's belief that there was a fundamental mystery in the world which could not be described or empirically evaluated, but could only be sung. Naming would become increasingly synonymous with the consciousness of the world; for this reason, more than any other, it was imperative that he continue to speak.

It is through their attention to orality that Neruda and Wright hoped to strengthen their bonds with country. Here, to make sense is to do so, quite literally: good stories make sense because they enliven the senses, they release the body from the constraints imposed on it by outworn, rigid ways of speaking, and they renew one's awareness of the world (Abram 265). David Abram therefore proposes that a genuinely ecological approach to dwelling would not work to attain a mentally envisioned future - one outlined by the structures of linear thought - but would strive 'to enter, ever more deeply, into the sensorial present' (272). The task, as he sees it, is to take up the potency of the written word and carefully write 'language back into the land'. Writers should be 'Planting words, like seeds, under rocks and fallen logs - letting language take root, once again, in the earthen silence of shadow and bone and leaf' (273). This seems an excellent epitaph for both Judith Wright and Pablo Neruda, the latter of whom, says Franco, sought a poetic that broke 'the wall of silence round crystal, wood and stone' (13).

For Wright as for Neruda, singing up country was a process of active, empathetic communication with the earth, which was both a home for objects of the natural world and the source of regenerative, creative potential. Singing involved a search for 'that last and faceless pool' ('The Lost Man'), where dialogue was as much a dissolution of one's self into the land as a heightened sensitivity to what the land itself might be saying. Written at the height of her powers, 'The Lost Man' was to be one of Wright's most emphatic, prescriptive accounts of how the individual must negate her self in order to find, 'between breath and death', 'the sun' by 
which she lives (Selected 83-84). Wright was far more positive and optimistic about her role as a poet and her ability to instigate material change earlier in her career. Nevertheless, although the demands of her political activity took her away from poetry, her essays and critical work show that her belief in the vitality and importance of the creative spirit never diminished. Thankfully, her presence in Australian letters has remained strong almost a decade after her death; with hope, then, a dialogue between the songs of Neruda and Wright might strengthen the pair's presence across continents, languages and the decades ahead.

\section{Works Cited}

Abram, David. The Spell of the Sensuous: Perception and Language in a More-ThanHuman World. 1996. New York: Vintage, 1997.

Brock, Werner. 'An Account of "The Four Essays".' Existence and Being. Ed. Werner Brock. Chicago: Henry Regnery, 1949. 117-231.

Brotherson, Gordon. Latin American Poetry: Origins and Presence. Cambridge: Cambridge UP, 1975.

Clarke, Patricia, and Meredith McKinney, eds. With Love and Fury: Selected Letters of Judith Wright. Canberra: National Library of Australia, 2006.

Cooke, Stuart. 'What Spain Was (trans).' Overland 189 (2007): 76.

Franco, Jean. Introduction. Pablo Neruda: Selected Poems. Ed. Nathaniel Tarn. London: Penguin, 1975. 1-21.

Harrison, Martin. Who Wants 10 Create Australia? Essays on Poetry and Ideas in Contemporary Australia. Sydney: Halstead, 2004.

Heidegger, Martin. 'Building Dwelling Thinking.' Poetry, Language, Thought. Ed. Albert Hofstadter. New York: Harper Colophon, 1971. 145-61.

_. Existence and Being. Trans. Douglas Scott, R.F.C. Hull and Alan Crick. Chicago: Henry Regnery, 1949.

- 'Hölderlin and the Essence of Poetry.' Trans. Douglas Scott. Existence and Being. Ed. Werner Brock. Chicago: Henry Regnery, 1949. 270-91.

- 'The Question Concerning Technology.' Basic Wiritings. Ed. David Farrell Krell. New York: Harper \& Row, 1977. 287-317.

—. 'What Are Poets For?' Poetry, Language, Thought. Ed. Albert Hofstadter. New York: Harper Colophon, 1971. 89-142.

Marett, Allan. Songs, Dreamings, and Ghosts: The Wangga of North Australia. 2005 ed. Middletown, Connecticut: Wesleyan UP, 2005.

Neruda, Pablo. Canto general. Trans. Jack Schmitt. 1991. Berkeley: U of California P, 2000.

- Crepusculario. 1923. Santiago: Andres Bello, 1995.

—. Odas elementales. 1954. Madrid: Catedra, 1990.

—. Tercera Residencia. 1947. Barcelona: Debolsillo, 2003.

—. Veinte poemas de amor y una canción desesperada. 1924. Ed. Dominic Moran. Manchester: Manchester UP, 2007.

Reid, Alastair. Introduction. Pablo Neruda: Selected Poems. Ed. Nathaniel Tarn. Boston: Houghton Miflin, 1990. 3-8.

Rigby, Kate. 'Earth, World, Text: On the (Im)Possibility of Ecopoiesis.' New Literary' History 35.3 (2004): 427-42.

Rose, Deborah Bird. Reports fiom a Wild Country: Ethicis for Decolonisation. Sydncy: U of New South Wales P, 2004. 
Rosenfeld, Andree. 'Structural Convergence in Arrernte Art and Song.' Many Exchanges: Archaeology. History, Comminity and the Work of Isabel Mcbryde. Ed. Ingereth Macfarlane, Mary-Jane Mountain and Robert Paton. Canberra: Aboriginal History, 2005. 171-84.

Walker, Shirley. Flame and Shadow: A Study of Judith Wright's Poetry. St Lucia: U of Queensland P, 1991.

Williamson, Edwin. The Penguin History of Latin America. London: Penguin, 1992. Wright, Judith. Because I Was Invited. Melboume: Ox ford UP, 1975.

- The Gateway. Sydney: Angus \& Robertson, 1953.

The Moving Image. Melbourne: Meanjin, 1946.

- Selected Poems: Five Senses. A \& R Modern Poets. 1976. North Ryde: Angus \& Robertson, 1989.

- Woman 1o Man. Sydney: Angus \& Robertson, 1949. 